\title{
THE INCIDENCE OF OSTEOGENIC SARCOMA IN SOUTH-WEST ENGLAND AND ITS RELATIONSHIP TO PAGET'S DISEASE OF BONE
}

\author{
C. H. G. Price, * Bristol, England
}

From the Pathology Research Laboratory, Department of Pathology, University of Bristol

This paper records the number of observed cases and the calculated incidence of the commonest type of bone sarcoma-osteogenic sarcoma-in south-west England during the thirteen years from 1946 to 1958 inclusive. Only estimates of the incidence of osteogenic sarcoma have hitherto been published; the data here given are believed to be based upon a very high proportion of all cases in the specified area, though obviously not all.

\section{METHODS}

This survey includes all known cases of the three established histological variants of osteogenic sarcoma-osteoblastic, chondroblastic and fibroblastic. The reasons for grouping these types of bone sarcoma under the generic term "osteogenic" were outlined in an earlier publication (Price 1961). Chondrosarcoma and malignant giant-cell tumour are excluded from this study. The histological types of the whole series of eighty-seven tumours are given in Table I. Most of this material (87 per cent) came from the Bristol Bone Tumour Register

TABLE I

Histological Varieties in Eighty-seven Osteogenic Sarcomata

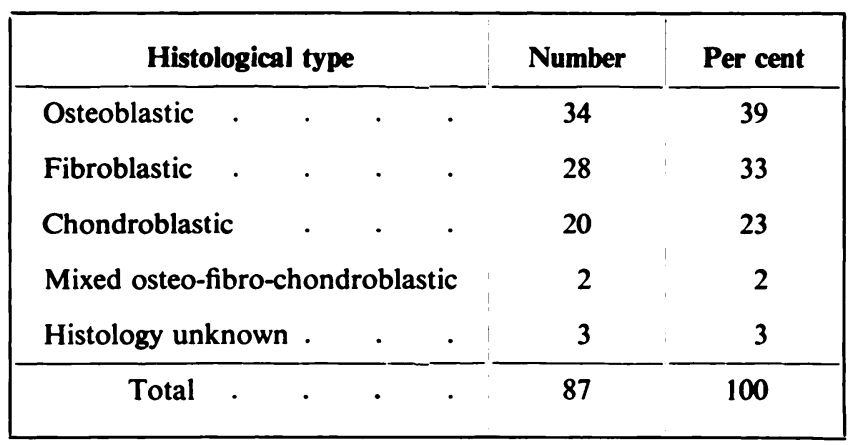

and was checked against a complete list of primary bone sarcoma in the Regional Cancer Records Bureau of the South-west Regional Hospital Board, which covers the city and county of Bristol, the county boroughs of Bath and Gloucester, and the counties of Somersetshire, Gloucestershire and most of Wiltshire, with a total resident population of approximately 1.56 millions in 1951. This is the "specified area" of this study and it probably has a more static population than many other parts of England, with an estimated annual migration in and out of population under 1 per cent per annum.

All examples of osteogenic sarcoma traced from the Regional Cancer Records Bureau had a careful scrutiny of the original case notes and, where available, the radiographs and histological material, so that nearly all -97 per cent-were verified histologically. The 3 per cent were cases in which no histological investigation was ever made, but in which the history and radiographs left an experienced panel in no reasonable doubt of the correct diagnosis. Furthermore, lists from the medical records officers of the larger hospitals of the area were

* Research Fellow in Pathology, University of Bristol. 
also examined, so that it can be claimed that this study includes all cases of osteogenic sarcoma treated in the hospitals throughout the specified area for thirteen years.

It is possible that a very small number of cases could have been missed if the patient were treated outside the hospital service in private practice; or if the tumours arose in very old patients

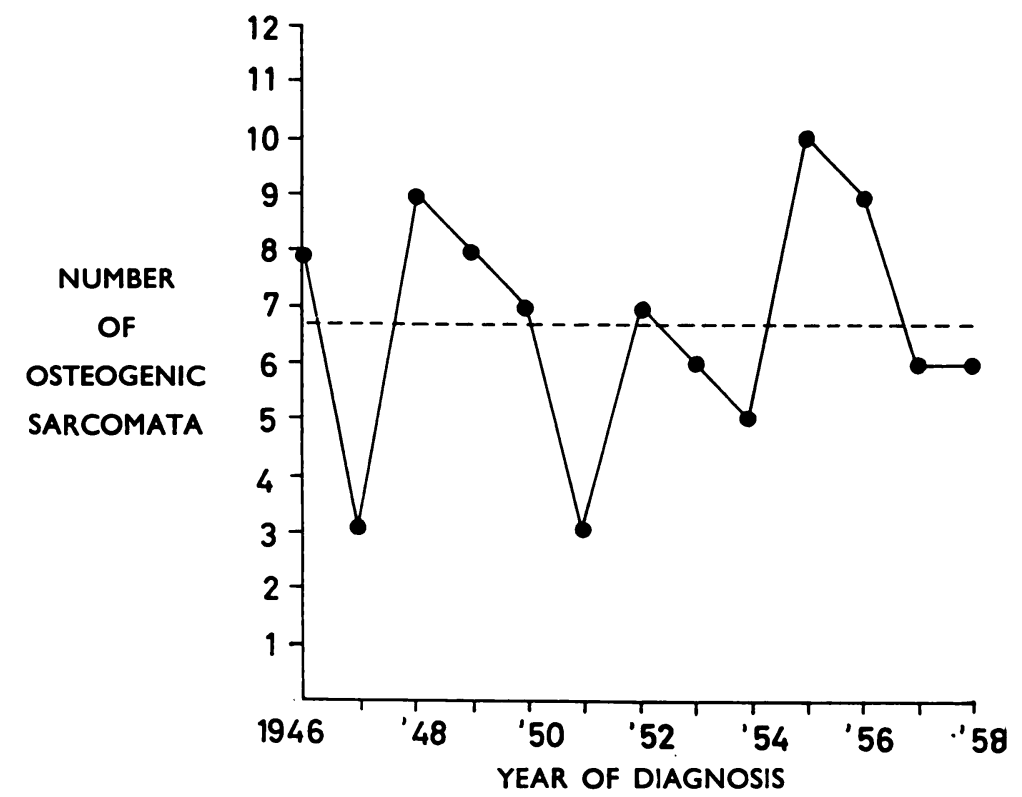

FIG. 1

Number of osteogenic sarcomata each year plotted against the year of occurrence.

The dotted line shows the mean value $(6 \cdot 7)$.

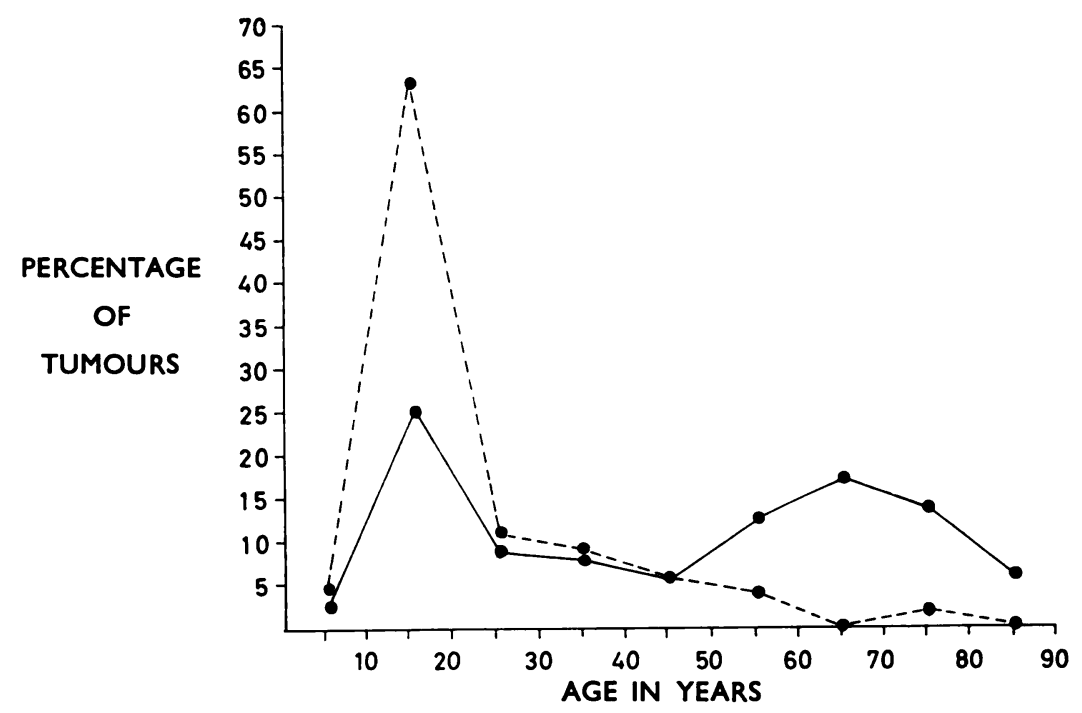

Fig. 2

The crude age distribution of two series of osteogenic sarcomata; the solid line being that of South-west England, and the broken line that of Norway (Eide, Aakhus and Stokke 1958). There is a bimodal distribution of the English series.

who were not admitted to hospital; and finally if a skeletal lesion in a middle-aged or older person were misdiagnosed as a metastatic carcinoma when there was a suggestive antecedent history. This class is the most likely source of any discrepancy between the actual number of

VOL. 44 B, NO. 2, MAY 1962 
tumours which arose and the number recorded here, which may underestimate the incidence in the age group over fifty-five years by 10 or 15 per cent.

Analysis of records-The annual totals are given in Figure 1 and Table II.

The average of 6.7 tumours diagnosed each year was equivalent to one tumour in every 230,000 persons, or 0.43 tumours per 100,000 persons.

The basic data for age and sex are given in Figure 2 and Table III, in which it is seen that osteogenic sarcoma is much more common in the elderly than in adolescents; this was suggested in an earlier paper (Price 1955); Figure 3 also shows this well.

Sex distribution-The uncorrected sex factor of 1.3 males to 1 female is typical of any large series (Price 1958): other published figures are shown in Table IV.

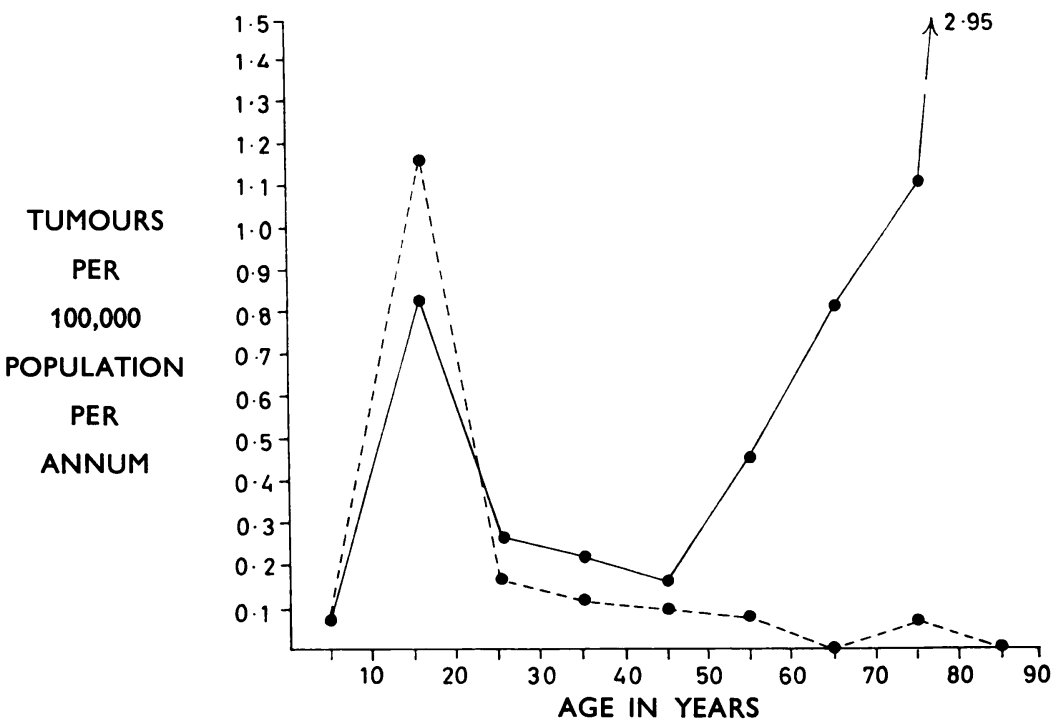

FIG. 3

The incidence, from the same series as Figure 2, of osteogenic sarcoma per 100,000 population plotted by decades; the solid line being that of South-west England, and the broken line that of Norway. There is a general similarity until the age of forty-five, at which time Paget's disease starts to appear.

\section{THE RELATIONSHIP TO PAGET'S DISEASE OF BONE}

Table II shows that of eighty-seven osteogenic sarcomata twenty-six, or 30 per cent, were associated with Paget's disease. In the full records of the Bristol Bone Tumour Registry (which include a number of cases referred from outside the specified area) there are now thirty-six examples of Paget's sarcoma among 141 consecutive osteogenic sarcomata (25 per cent). Thomson and Turner-Warwick (1955) found fifteen Paget's sarcomata in 135 primary bone sarcomata (11 per cent), and Platt (1947a and $b$ ) found ten such tumours out of 161 primary malignant sarcomata of bone $(6 \cdot 2$ per cent). Table $\mathrm{V}$ shows the histology of the Paget's sarcomata.

Table III indicates the incidence of Paget's sarcoma alone- $0 \cdot 18$ per 100,000 population; this high figure appears to be representative and not due to any desire to record unusual cases as suggested by Coventry and Dahlin (1957).

Collins (1956) found evidence of Paget's disease in 3.7 per cent of 650 unselected serial necropsies on cadavers over the age of forty (equivalent to 1.6 per cent in persons of all ages). This is similar to the 4.4 per cent of incidental Paget's disease found by Fergusson (1958) in 313 men over forty-five with carcinoma of the prostate, although the skeletal lesions were not histologically verified. Collins's incidence figure is about twice that obtained by Hobson and 
Pemberton (1955) who, by estimating the serum alkaline phosphatase, discovered eight examples of Paget's disease in seventy men over sixty-five and ninety-two women over sixty in Sheffield-giving an incidence of 4.9 per cent, or 0.7 per cent of persons of all ages. This survey is likely to be low because in early cases the alkaline phosphatase may be normal. All of these English figures, however, considerably exceed that of 0.12 per cent of Paget's disease reported by Rosenkrantz, Wolf and Kaicher in 1952 in the Bronx.

If the incidence of 1.6 per cent for Paget's disease in all ages given by Collins (1956) is accepted it may then be calculated that at any given time there are about 26,000 persons with Paget's disease in the specified area, of whom the vast majority are symptomless. Dickson, Camp and Ghormley (1945) found that 20 per cent of 367 cases of Paget's disease had no symptoms.

TABLE II

Number of Osteogenic Sarcomata Diagnosed in the Specified Area from 1946 to 1958

\begin{tabular}{|c|c|c|c|c|}
\hline $\begin{array}{c}\text { Year of } \\
\text { diagnosis }\end{array}$ & Males & Females & Total & $\begin{array}{l}\text { Number with } \\
\text { Paget's disease }\end{array}$ \\
\hline 1946 & 4 & 4 & 8 & 2 \\
\hline 1947 & 2 & 1 & 3 & - \\
\hline 1948 & 6 & 3 & 9 & 2 \\
\hline 1949 & 5 & 3 & 8 & 2 \\
\hline 1950 & 3 & 4 & 7 & 2 \\
\hline 1951 & 1 & 2 & 3 & 3 \\
\hline 1952 & 4 & 3 & 7 & 4 \\
\hline 1953 & 1 & 5 & 6 & 3 \\
\hline 1954 & 1 & 4 & 5 & 1 \\
\hline 1955 & 9 & 1 & 10 & 2 \\
\hline 1956 & 7 & 2 & 9 & 2 \\
\hline 1957 & 2 & 4 & 6 & 一 \\
\hline 1958 & 4 & 2 & 6 & 3 \\
\hline Total . & $\begin{array}{c}49 \\
(17 \text { with } \\
\text { Paget's disease) }\end{array}$ & $\begin{array}{c}38 \\
\text { (9 with } \\
\text { Paget's disease) }\end{array}$ & 87 & 26 \\
\hline $\begin{array}{l}\text { Mean value per } \\
\text { annum }\end{array}$ & $3.8 \pm 0.65$ & $2.9 \pm 0.34$ & $6.7 \pm 0.58$ & $2 \cdot 0$ \\
\hline
\end{tabular}

The age incidence curve of Paget's disease begins to climb steeply after the fifth decade, and Kay, Simpson and Riddoch (1934) found that the mean age of onset in thirty-four patients was forty-six years. Packard, Steele and Kirkbride (1901) found the average age of onset to be 49.5 years in fifty-one patients, and Dickson et al. (1945) about forty-six years. These findings suggest that the average duration of Paget's disease is about twenty years, with an average expectation of life in England of sixty-seven for men and seventy-four for women. On these assumptions one may estimate the frequency with which sarcoma complicates Paget's disease; twenty-six Paget's sarcomata collected in thirteen years is equivalent to forty in twenty years in a population of 26,000 persons with Paget's disease, which means that about one person in 650 with the disease will develop a sarcoma ( 0.15 per cent) or 154 out of every 100,000 with Paget's disease. This figure may be compared with that of 0.9 per cent derived from the Mayo Clinic records by Porretta, Dahlin and Janes (1957), the reason for the difference

VOL. 44 B, NO. 2, MAY 1962 
being that there are numerous cases of symptomless Paget's disease of limited extent and severity (Jaffe 1958, Price 1956a).

The incidence of one sarcoma among 650 persons with Paget's disease is high, and shows about a thirty-fold increase of the risk of sarcoma in persons over forty compared with the

TABLE III

Incidence of Osteosarcoma in Relation to Age, Sex and Paget's Disease

\begin{tabular}{|c|c|c|c|c|c|c|c|c|}
\hline & & & & Number & Per cent & Population & & $\begin{array}{l}\text { idence per } 100,000 \\
\text { per annum }\end{array}$ \\
\hline \multicolumn{9}{|c|}{ Sex } \\
\hline Males & . & . & . & 49 & 56 & 732,000 & 0.527 & \multirow{2}{*}{$\begin{array}{l}\text { Corrected sex factor } \\
1.44 \text { male:female }\end{array}$} \\
\hline Females & . & . & . & 38 & 44 & 824,000 & 0.36 & \\
\hline Total & . & - & - & 87 & 100 & $1,560,000$ & 0.43 & $(1$ in 230,000$)$ \\
\hline \multicolumn{9}{|c|}{ Age groups in years } \\
\hline \multicolumn{9}{|c|}{ Adolescent group } \\
\hline & \multicolumn{4}{|c|}{ Intermediate age group } & 22 & 610,000 & $0 \cdot 24$ & \\
\hline \multicolumn{8}{|c|}{ Senile group } & \\
\hline \multicolumn{9}{|c|}{ Paget's disease } \\
\hline All ages & . & - & - & 26 & 30 & $1,560,000$ & $0 \cdot 18$ & $\begin{array}{l}\text { Overall incidence of } \\
\text { Paget's sarcoma }\end{array}$ \\
\hline Over 55 & years & - & - & 23 & 60 & 393,000 & 0.45 & \\
\hline \multicolumn{9}{|c|}{$\begin{array}{l}\text { Senile group } \\
\text { with osteosarcoma but } \\
\text { no Paget's disease }\end{array}$} \\
\hline Over 55 & years & - & - & 15 & 40 & $367,000 *$ & 0.32 & \\
\hline
\end{tabular}

* Total population over fifty-five years, less 26,000 estimated to have Paget's disease.

TABLE IV

Published Figures of the Uncorrected Sex Factor in Osteosarcomata

\begin{tabular}{|c|c|c|c|c|c|c|}
\hline \multicolumn{4}{|c|}{ Author } & \multirow{2}{*}{$\begin{array}{c}\text { Country } \\
\text { United States of America }\end{array}$} & \multirow{2}{*}{$\frac{\text { Year }}{1925}$} & \multirow{2}{*}{$\begin{array}{c}\begin{array}{c}\text { Uncorrected } \\
\text { sex factor } \\
\text { male to female }\end{array} \\
1.4\end{array}$} \\
\hline Christensen . & . & & . & & & \\
\hline Cade . & . & & . & England & 1955 & $1 \cdot 5$ \\
\hline \multicolumn{4}{|c|}{ Thomson and Turner-Warwick } & England & 1955 & 1.9 \\
\hline \multicolumn{4}{|c|}{ Coventry and Dahlin . } & United States of America & 1957 & $1 \cdot 7$ \\
\hline \multicolumn{4}{|c|}{ Eide, Aakhus and Stokke } & Norway & 1958 & $1 \cdot 1$ \\
\hline Jaffe . . & . & & . & United States of America & 1958 & $2 \cdot 0$ \\
\hline
\end{tabular}

normal, in whom the equivalent incidence rate for the same age is $5 \cdot 2$ per 100,000 for a twenty-year period. The risk increases with advancing age with Paget's disease, to which were related nine out of twelve tumours in the eighth decade in this series. This is different from the findings attributed to Codman by Kolodny (1927) that 14 per cent of all cases of Paget's 
disease were eventually complicated by sarcoma, and from the high incidences quoted by other writers shown in Table VI.

\section{DISCUSSION}

The incidence of osteogenic sarcoma-In the present series the total incidence for this tumour is about one in every 230,000 of the population per annum. The mean survival of these patients has been three years (Price 1956b, 1961); hence, at any given time in the specified

TABLE V

Comparison of the Histological Structure of THE Twenty-six Paget's Sarcomata with the Whole Present Series

\begin{tabular}{|c|c|c|c|c|}
\hline \multirow{2}{*}{ Histological type } & \multicolumn{2}{|c|}{ Paget's sarcomata } & \multirow{2}{*}{$\begin{array}{c}\text { Number } \\
\text { in } \\
\text { whole series }\end{array}$} & \multirow{2}{*}{$\underset{\substack{\text { Portional } \\
\text { percentage }}}{\text { Pro- }}$} \\
\hline & Number & Per cent & & \\
\hline Osteoblastic & 8 & 31 & 34 & 23 \\
\hline Fibroblastic . & 13 & 50 & 28 & 64 \\
\hline Chondroblastic & 4 & 15 & 20 & 20 \\
\hline No histology . & 1 & 4 & 3 & - \\
\hline
\end{tabular}

TABLE VI

Percentage of Paget's Disease Complicated by Sarcomata FROM THE LITERATURE

\begin{tabular}{|c|c|c|c|}
\hline \multicolumn{2}{|c|}{ Author } & Year & Percentage \\
\hline Gruner, Scrimger and Foster . & $\cdot$ & 1912 & 9 \\
DaCosta, Funk, Bergheim and Hawk & 1915 & 9 \\
Bird . . . . . &. & 1927 & 11 \\
Locke, quoted by Bird . . . &. & 1927 & 6.2 \\
Rosenkrantz, Wolf and Kaicher &. & 1952 & $7 \cdot 2$ \\
\hline
\end{tabular}

area the incidence would be approximately one tumour to 80,000 of the population. This figure is twice that reported by Platt (1935), bearing in mind that only about half of any series of primary bone sarcomata are osteogenic. Platt also drew attention to the somewhat higher incidence of the tumour in Great Britain than in the United States of America. Other published estimates for the incidence of osteogenic sarcoma are shown in Table VII.

In the Bristol Bone Tumour Registry records 55 per cent of all primary bone sarcomata are osteogenic, so there may possibly be an increased incidence of this tumour in England when compared with the United States of America, but there may well be other reasons for the different incidence.

The present paper is intended not only to record the incidence in the specified area, but also to emphasise the importance of age, with special reference to the high incidence in persons over fifty-five. The neoplasm is relatively rare before puberty-in this series 13 per cent, which is about the usual figure.

The age incidence curve of osteogenic sarcoma may have a significance beyond the demonstration of present racial differences due to the frequency or otherwise of Paget's disease (vide infra). As the utilisation of nuclear energy for domestic and industrial purposes increases there may periodically occur other insidious mishaps such as that which befell the 
Calder Hall nuclear reactor in October 1957. Moreover, the world-wide concern over the biological effects of nuclear fall-out consequent upon the continued testing of atomic weapons prompts the recording of basic incidence data for osteogenic sarcoma, this being a neoplasm readily induced in man and other species by bone-seeking isotopes. Some of the broader aspects of these problems and the known increase of radioactivity in sampled bones have been briefly discussed in an editorial in the British Medical Journal (1960). $\mathrm{Sr}^{89}$ and $\mathrm{Sr}^{90}$ are

TABLE VII

Incidence of Primary Bone Sarcomata from the Literature

\begin{tabular}{|cccc|c|}
\hline Author & Year & Place & Incidence at any time \\
\hline Kolodny & 1927 & Massachusetts & 1 per 100,000 \\
Platt & $\cdot$ & 1935 & Manchester, England & 1 per 75,000 \\
Coley & $\cdot$ & 1949 & United States of America & 1 per 100,000 \\
Coley & $\cdot$ & 1949 & United States of America & 1 per 117,000 \\
\hline
\end{tabular}

TABLE VIII

The Incidence of Osteogenic Sarcomata Compared by Age of Patient in Norway and England

\begin{tabular}{|c|c|c|c|c|c|c|c|c|c|}
\hline \multirow{2}{*}{$\begin{array}{l}\text { Age } \\
\text { in } \\
\text { years }\end{array}$} & \multirow[b]{2}{*}{$\begin{array}{l}\text { Total at } \\
\text { each } \\
\text { age }\end{array}$} & \multicolumn{2}{|c|}{ Norway } & \multirow{2}{*}{$\begin{array}{c}\text { Incidence } \\
100,000 \\
\text { per annum } \dagger\end{array}$} & \multirow{2}{*}{$\begin{array}{c}\text { Total at } \\
\text { each } \\
\text { age }\end{array}$} & \multicolumn{3}{|c|}{ England (South-west) } & \multirow[b]{2}{*}{$\begin{array}{c}\text { Incidence } \\
100,000 \\
\text { per annum } \S\end{array}$} \\
\hline & & $\begin{array}{l}\text { Per cent } \\
\text { of total }\end{array}$ & $\begin{array}{c}\text { Population } \\
\times 100,000 \\
\left(1952^{*}\right)\end{array}$ & & & $\begin{array}{l}\text { Per cent } \\
\text { of total }\end{array}$ & $\begin{array}{l}\text { Number with } \\
\text { Paget's } \\
\text { disease }\end{array}$ & $\begin{array}{c}\text { Population } \\
\times 100,000 \\
\left(1952^{\ddagger}\right)\end{array}$ & \\
\hline $0-9$ & 3 & $4 \cdot 5$ & $6 \cdot 08$ & 0.06 & 2 & $2 \cdot 3$ & - & $2 \cdot 4$ & 0.06 \\
\hline $10-19$ & 42 & $63 \cdot 4$ & $4 \cdot 20$ & $1 \cdot 17$ & 22 & $25 \cdot 3$ & - & $2 \cdot 04$ & $0 \cdot 83$ \\
\hline $20-29$ & 7 & $10 \cdot 6$ & $7 \cdot 73$ & $0 \cdot 17$ & 8 & $9 \cdot 2$ & - & $2 \cdot 28$ & $0 \cdot 27$ \\
\hline $30-39$ & 6 & $9 \cdot 0$ & $5 \cdot 20$ & $0 \cdot 12$ & 7 & $8 \cdot 1$ & 一 & $2 \cdot 29$ & $0 \cdot 23$ \\
\hline $40-49$ & 4 & $6 \cdot 0$ & $4 \cdot 58$ & $0 \cdot 10$ & 5 & $5 \cdot 7$ & 1 & $2 \cdot 32$ & $0 \cdot 17$ \\
\hline $50-59$ & 3 & $4 \cdot 5$ & $3 \cdot 80$ & 0.09 & 11 & $12 \cdot 6$ & 7 & $1 \cdot 83$ & $0 \cdot 46$ \\
\hline $60-69$ & - & - & $2 \cdot 56$ & - & 15 & $17 \cdot 3$ & 7 & $1 \cdot 40$ & $0 \cdot 82$ \\
\hline $70-79$ & 1 & $2 \cdot 0$ & $1 \cdot 54$ & 0.08 & 12 & $13 \cdot 8$ & 9 & $0 \cdot 83$ & $1 \cdot 11$ \\
\hline $80-89$ & - & - & 0.57 & - & 5 & $5 \cdot 7$ & 2 & $0 \cdot 13$ & $2 \cdot 95$ \\
\hline Totals & 66 & $100 \cdot 0$ & $33 \cdot 20$ & $0 \cdot 32$ & 87 & $100 \cdot 0$ & 26 & $15 \cdot 6$ & 0.43 \\
\hline
\end{tabular}

* Total civil population 1952, from Table on pp. 1 and 2 of Cancer Death Rates by Site, Age and Sex (Case and Harley 1958).

$\dagger$ Corrected on basis of series collected in nineteen years (1938-56); representing 45 per cent of all registrations of osteogenic sarcomata in Norway (Eide et al. 1958).

+ Mean percentages for five years (1948-52) of total civil population of England and Wales (from Table A2, Registrar General's Statistical Review of England and Wales for the year 1952, Tables Part II); five-year means applied to 1951 population of specified area.

$\$$ Based upon thirteen years' collection of all known proven cases of osteogenic sarcomata in specified area.

the important bone-seeking isotopes which man may inadvertently consume-mainly from contaminated food-and it has been shown that rather more than half the ingested radioactivity comes from milk (Agricultural Research Council 1960). Since milk as a beverage is drunk mainly by children and young adults, one may forecast that sustained rising radioactivity would be reflected not only by a total increase in the numbers of osteogenic sarcomata presenting but also by a distortion of the present age incidence curves with a relative increase among 
juveniles. The biologically noxious threshold of dosage of these isotopes and their latent periods for man are unknown, although some guidance may perhaps be obtained from past experience with radium and radiotherapeutic irradiation. Furthermore, the present long bone preponderance may well diminish, with more tumours arising in those bones mainly of cancellous structure.

The relationship to Paget's disease of bone-Eide, Aakhus and Stokke (1958) stated that thirty-five new cases of osteogenic sarcoma were registered annually with the Norwegian Cancer Registry during the years 1952-56 inclusive, and that in their own series of 194 primary bone sarcomata, 30.4 per cent were osteogenic, and that 45.1 per cent of all Norwegian registrations were treated as patients at the Norwegian Radium Hospital in Oslo (1938-56). Since the mid-1952 population of Norway was 3.32 millions (Case and Harley 1958), the incidence of osteogenic sarcoma for all ages was 0.32 per 100,000 population per annum. This overall figure agrees closely with that of 0.43 per 100,000 obtained in the present work. There is, however, an important difference in the age distribution of the two series of sarcomata. In this series 44 per cent of the patients were over fifty-five years of age, while only 6 per cent of Eide's were over this age, and there was a very pronounced juvenile peak in the second decade. Table VIII and Figures 2 and 3 show the age distributions and incidences of these two series,

TABLE IX

Proportion of Paget's Sarcoma in Published Series of Osteogenic Sarcomata

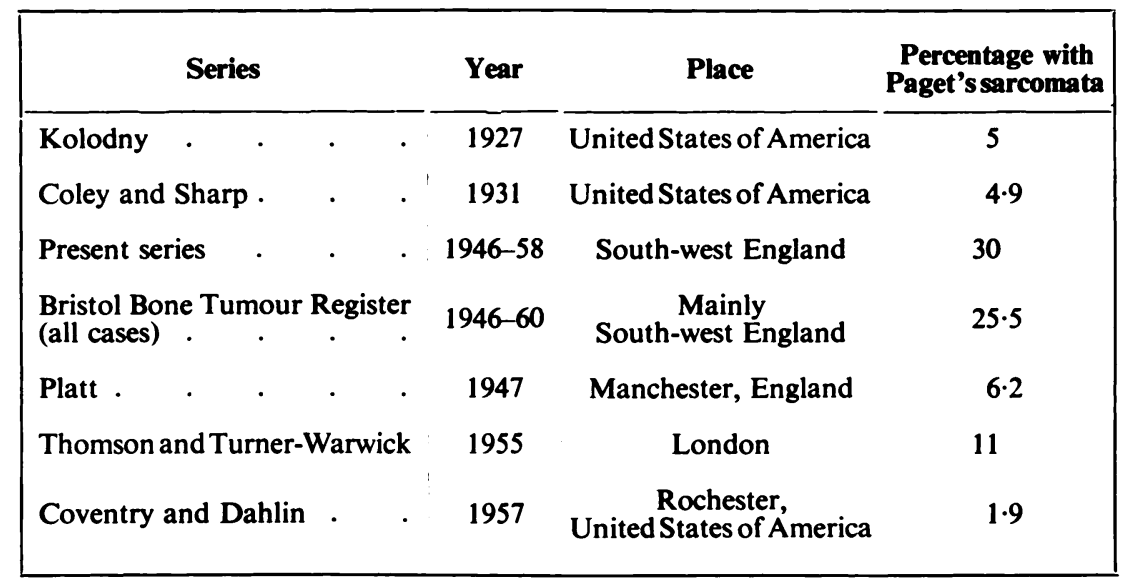

in which the difference between the older age groups and the similarity of the younger are well shown. Clearly the racial contrast lies not in any increased incidence in Norway among the juveniles, but the absence in that country of tumours of older persons as seen in the specified area. It is significant that no reference to Paget's sarcoma is made by Eide et al. (1958), by Eker and Poppe (1942), by Poppe (1949) or by Pederson and Magnus (1959). One may assume that Paget's sarcoma is at least uncommon in Norway, as is stated also to be the case in Sweden (Bauer 1960). Such may also be the position among certain other races, as, for example, the Madras Indians (Menon 1955).

A comparison is made in Table IX of the proportion of Paget's sarcomata in various published series of osteogenic sarcomata.

Jaffe (1958) stated: "Occasionally a patient with osteogenic sarcoma is in his fifties," and Lichtenstein (1952) remarked that, at the time of reviewing all his bone sarcomata, there were but six examples of Paget's sarcoma. Thus, while Paget's sarcoma is rare in the United States of America and Norway, it is much more common in England.

Sarcoma does not seem to be a more frequent complication of Paget's disease in England than elsewhere, because it occurred in 0.15 per cent of Paget's disease in this series, and in 0.9 per cent in the series reported by Porretta et al. (1957).

vol. 44 B, NO. 2, MAY 1962 
There is, however, little doubt that Paget's disease is more common in south-west England than in the United States of America and Scandinavia, although it is also probable that there is an incidence gradient of Paget's disease in Britain; the condition may diminish in frequency as one proceeds northwards and is stated to be less common in Aberdeenshire (Hendry 1960). Paget's disease is said to be about as common in Australia as in England (Willis 1960). Collins (1956) compared his finding of 3.7 per cent in cadavers over forty years of age with Paget's disease to the 3 per cent found by Schmorl in south Germany in 1932. In the United States of America Monroe (1951) found eighty-five cases of Paget's disease among 7,941 persons over sixty-one years of age who were patients of the Peter Bent Brigham Hospital at Boston during the period 1913 to 1943 . This represents 1.06 per cent of the total, or 0.13 per cent of persons of all ages; 75 per cent of these patients were from the New England states, Canada, or of British extraction. In Holland Paget's disease is said to be less common than in England, and the proportion of osteogenic sarcomata with concomitant Paget's disease is under 5 per cent (van der Heul 1960). Koller (1946) estimated the incidence of Paget's disease among the Swiss of Zürich to be one in 7,700 persons over thirty years of age, or 0.024 per cent of all ages.

Paget's disease and, therefore, Paget's sarcoma must reflect the age of the population. Comparable figures for the proportion of persons over the age of fifty-five years are 23.6 per cent in south-west England, 16.9 per cent in the United States of America, and 17.2 per cent in Norway. These inequalities in age distribution are inadequate to account for the difference of incidence of Paget's sarcoma between these three countries.

The reasons for these racial differences are unknown, but the cause must lie in heredity and environment, and the elucidation of the part played by each represents one of the most important unsolved problems in the general study of all forms of cancer (Steiner 1954). Such meagre information as the author possesses suggests that Paget's disease is seen in southern Australia among a migrant European population which is mainly of British origin at about the same order of frequency as in England and Wales, and, conversely, the condition is rarely seen among Scandinavians resident in North America. This incomplete information suggests that the racial incidence of Paget's disease is influenced more by heredity than by environment. Although familial examples of the disease are rarely reported, Galbraith (1954) mentioned that there were at least seventy-seven instances in the literature, whilst individual surveys have disclosed a familial trait in proportions varying between 3.5 per cent (Gutman and Kasabach 1936) to 20.8 per cent (Locke 1943). McKusick (1960), in a review of the heredity of Paget's disease, makes no comment upon racial differences, but expresses the view that " the trait for Paget's disease is controlled by a simple autosomal Mendelian-dominant gene."

The relationship of Paget's disease to other forms of osteoporosis is unknown, particularly if there may be a familial connection. This may have significance in connection with osteogenic sarcoma in the elderly, because the proportion of patients over fifty-five years of age in this series, but without Paget's disease, is considerably greater than that reported in the Norwegian records.

Obviously, Paget's disease and osteogenic sarcoma are quite often coexistent, but one is much less certain that the local osteitic lesion does in fact promote the neoplasm. The weight of evidence is that Paget's disease modifies the age, sex and site distribution of osteogenic sarcoma; but this, although suggestive, does not entirely prove the causal connection between the polyostotic skeletal abiotrophy and the usually monomelic sarcoma.

It is possible that those factors-whether of heredity or otherwise-responsible for osteitis may be linked with others that cause malignancy, but there is no evidence that persons with Paget's disease have an increased risk of cancer elsewhere than in bone. Indeed, there is a strong negative correlation between Paget's disease and multiple myeloma-a neoplastic condition with many similarities in its etiology. Several other diseases are sometimes associated with Paget's disease, such as diabetes mellitus and Hashimoto's lymphoid thyroiditis, but again this does not of necessity imply any causal relationship between these lesions and either 
Paget's disease or Paget's sarcoma. Nevertheless, the metastatic calcification of blood vessels and calculus formation one may well accept as being in some part consequent upon the intrinsic metabolic disturbance of the continued skeletal turmoil of Paget's disease.

\section{SUMMARY}

1. The average number of cases of osteogenic sarcoma found in the years 1946-58 inclusive in the northern division of the South-west Hospital region of England was 6.7 for each year, varying from three to ten.

2. The annual incidence of this sarcoma in this area was one tumour per 230,000 population. 3. These figures were compared with similar figures from Norway which indicate a rather similar tumour incidence among juveniles, but a very much smaller number of tumours in elderly persons.

4. Among the eighty-seven sarcomata collected in the specified area in thirteen years twentysix were associated with Paget's disease.

5. It is estimated that among the population of the specified area there were probably 26,000 persons at any time with Paget's disease, of whom one in 650 ( 0.15 per cent) would eventually develop sarcoma.

6. This study suggests that Paget's disease increases the risk of sarcoma about thirty-fold in persons over forty years of age.

7. It is tentatively suggested that the incidence of Paget's disease is influenced more by heredity than environment.

It is impossible here to acknowledge the individual assistance of all who have over the years contributed to the material upon which this present study is based. The author must however thank all the members of the panel of the Bristol Bone Tumour Registry for the provision of the great majority of the cases included in this survey and for their sustained interest; two members especially-Dr F. G. M. Ross and Dr A. L. Taylor-have greatly aided the author by reading, discussing and criticising the original draft of this paper. Thanks are also due to Major R. Leyland, Registrar of the South-west Regional Cancer Records Bureau, for comprehensive annual records and much information about the specified area. The author is also indebted to Sir Harry Platt, Professor R. A. Willis, Professor R. Bauer, Mr N. G. C. Hendry, Dr R. O. van der Heul, and many others who have given advice drawn from their personal experience. Indispensable services have also been rendered by the Medical Records Officers and their staffs of many hospitals in checking and compiling lists of cases, for which help the author's thanks must be recorded.

This present study and the Bristol Bone Tumour Register have been supported by grants from the British Empire Cancer Campaign and from the University of Bristol Cancer Research Fund.

\section{REFERENCES}

Agricultural Research Council Radiobiological RePorts No. 2 (1960): London: Her Majesty's Stationery Office.

BAUER, R. (1960): Personal communication.

BIRD, C. E. (1927): Sarcoma Complicating Paget's Disease of the Bone. Archives of Surgery, 14, 1,187.

CADE, Sir S. (1955): Osteogenic Sarcoma. Journal of the Royal College of Surgeons of Edinburgh, 1, 79.

CaSe, R. A. M., and HARLeY, J. L. (1958): Cancer Death Rates by Site, Age and Sex. London: Chester Beatty Research Institute, Institute of Cancer Research, Royal Cancer Hospital.

Christensen, F. C. (1925): Bone Tumors. Annals of Surgery, 81, 1,074.

Coley, B. L. (1949): Neoplasms of Bone, p. 245. New York: Paul B. Hoeber, Inc.

Coley, B. L., and Sharp, G. S. (1931): Paget's Disease. Archives of Surgery, 23, 918.

Collins, D. H. (1956): Paget's Disease of Bone. Lancet, ii, 51.

Coventry, M. B., and DAhLin, D. C. (1957): Osteogenic Sarcoma. Journal of Bone and Joint Surgery, 39-A, 741.

DaCosta, J. C., Funk, E. H., Bergheim, O., and HaWk, P. B. (1915): Osteitis Deformans. Publications from the Jefferson Medical College and Hospital, 6, 1.

Demographic Year BoOK (1952): New York: United Nations.

Dickson, D. P., Camp, J. D., and Ghormley, R. K. (1945): Osteitis Deformans: Paget's Disease of the Bone. Radiology, 44, 449.

EDITORIAL (1960): British Medical Journal, i, 117.

EIDE, O., AAKhuS, T., and Stokke, T. (1958): Primary Bone Sarcoma. Skrifter utgitt av det Norske Videnskapsakademi i Oslo. I. Mat.-Naturv. Klasse. (Kommisjon Hos Jacob Dybwad. Oslo. Norge.) World Med. Publs. 2nd Ed. No. 4186.

VOL. 44 B, NO. 2, MAY 1962 
Eker, R., and Poppe, E. (1942): Primary Bone Sarcoma. Acta Radiologica, 23, 387.

Fergusson, J. D. (1958): The Treatment of Prostatic Cancer. Annals of the Royal College of Surgeons of England, 22, 237.

Galbraith, H.-J. B. (1954): Familial Paget's Disease of Bone. British Medical Journal, ii, 29.

Gruner, O. C., Scrimger, F. A. C., and Foster, L. S. (1912): A Clinical and Histological Study of a Case of Paget's Disease of the Bones with Multiple Sarcoma Formation. Archives of Internal Medicine, 9, 641.

Gutman, A. B., and Kasabach, H. (1936): Paget's Disease (Osteitis Deformans). American Journal of the Medical Sciences, 191, 361.

HeNDRY, N. G. C. (1960): Personal communication.

Hobson, W., and Pemberton, J. (1955): The Health of the Elderly at Home, p. 137. London: Butterworth \& Co. (Publishers) Ltd.

JAFFE, H. L. (1958): Tumors and Tumorous Conditions of the Bones and Joints, p. 257. London: Henry Kimpton.

Kay, D. H., Simpson, S. L., and Riddoch, G. (1934): Osteitis Deformans. Archives of Internal Medicine, 53, 208.

Koller, F. (1946): Úber die Heredität der Ostitis deformans Paget. Helvetica Medica Acta, Series A-13, 389.

Kolodny, A. (1927): Bone Sarcoma. Surgery, Gynecology and Obstetrics, Supplement 1, p. 71.

Lichtenstein, L. (1952): Bone Tumors, p. 171. London: Henry Kimpton.

LOCKE, E. A. (1943): Quoted in Oxford Medicine, volume 4, p. 426. New York: Oxford University Press.

Locke, E. R. (1927): Personal communication quoted by Bird, C. E. (1927).

McKusick, V. A. (1960): Heritable Disorders of Connective Tissue. Second edition. St Louis: The C. V. Mosby Company.

Menon, A. N. K. (1955): Osteitis Deformans or Paget's Disease in Madras. Indian Journal of Radiolog.', 9, 78.

Monroe, R. T. (1951): Diseases in Old Age. Cambridge, Mass.: Harvard University Press.

Packard, F. A., Steele, J. D., and Kirkbride, T. S., Jun. (1901): Osteitis Deformans. American Journal of the Medical Sciences, 122, 552.

Pederson, E., and Magnus, K. (1959): Cancer Registrations in Norway. Oslo: The Norwegian Cancer Society.

Platt, H. (1935): The Lady Jones Lecture on Malignant Tumours of Bone. Liverpool Medico-Chirurgical Journal, 43, 42.

Platt, H. (1947a): Survival in Bone Sarcoma. Journal of Bone and Joint Surgery, 29, 6.

Platt, H. (1947b): Sarcoma in Abnormal Bones. British Journal of Surgery, 34, 232.

Poppe, E. (1949): Osteogenic Sarcoma. Along What Lines Should it be Treated? Acta Radiologica, $31,335$.

Porretta, C. A., Dahlin, D. C., and Janes, J. M. (1957): Sarcoma in Paget's Disease of Bone. Journal of Bone and Joint Surgery, 39-A, 1,314.

Price, C. H. G. (1955): Osteogenic Sarcoma; an Analysis of the Age and Sex Incidence. British Journal of Cancer, 9, 558.

Price, C. H. G. (1956a): British Empire Cancer Campaign. Annual Report No. 34, p. 231.

Price, C. H. G. (1956b): The Grading of Osteogenic Sarcoma, and its Bearing upon Survival and Prognosis. Journal of the Faculty of Radiologists, 7, 237.

Price, C. H. G. (1958): Primary Bone-forming Tumours and their Relationship to Skeletal Growth. Journal of Bone and Joint Surgery, 40-B, 574.

Price, C. H. G. (1961): Osteogenic Sarcoma. Journal of Bone and Joint Surgery, 43-B, 300.

Registrar General's Statistical Review of England and Wales for the Year 1952. Tables, Part II (1953): London: Her Majesty's Stationery Office.

Rosenkrantz, J. A., Wolf, J., and Kaicher, J. J. (1952): Paget's Disease (Osteitis Deformans). Archives of Internal Medicine, 90, 610.

SchmoRL, G. (1932): Úber Ostitis deformans Paget. Virchows Archiv für pathologische Anatomie und Physiologie, 283, 694.

STEINER, P. E. (1954): Cancer: Race and Geography. Baltimore: The Williams and Wilkins Company.

Thomson, A. D., and Turner-Warwick, R. T. (1955): Skeletal Sarcomata and Giant-cell Tumour. Journal of Bone and Joint Surgery, 37-B, 266.

VAN Der Heul, R. O. (1960): Personal communication.

Willis, R. A. (1960): Personal communication. 